\title{
Malignancy in Giant Cell Tumor of Bone
}

National Cancer Institute

\section{Source}

National Cancer Institute. Malignancy in Giant Cell Tumor of Bone. NCI Thesaurus. Code C4304.

A malignant tumor that arises from the bone. It is characterized by the presence of an area of high grade sarcoma in an otherwise typical giant cell tumor (primary malignancy in giant cell tumor), or the presence of sarcoma in which the pre-existing giant cell tumor may or may not be apparent (secondary malignancy in giant cell tumor). 